\title{
The consumer behaviour and new brand management policies of organic food in Italy: the case study of "Vivi Verde Coop"
}

\author{
Aldo Marchese ${ }^{1}$, Matteo Masotti ${ }^{2}$, Katia Laura Sidali ${ }^{3}$, Andrea Cristina Dörr ${ }^{4}$ \\ ${ }^{1,2}$ University of Bologna - Bologna - Italy \\ ${ }^{3}$ Goerg August University Goettingen - Goettingen - Germany \\ ${ }^{4}$ Federal University of Santa Maria - Santa Maria - RS - Brazil
}

\begin{abstract}
Due to economic growth, social, cultural and demographic changes lead to changes on food production patterns. Increased instruction levels, strong urbanization and consequent depopulation of rural areas, increased number of working women, increased wealth of families, growth and differentiation of food demand led to deep innovations in consumers priorities and choices. It means that consumption behaviors are now more focused on food safety (search for secure, healthy and even biological food) rather than food security (the problem of food scarcity no longer affects the developed countries). Food producers and distributors, in particular large scale distribution, gradually adapted their strategies to meet the emerging consumers' preferences. In this paper we analyze the brand management strategy "ViviVerde" pursued by Coop and, also we perfom an analysis of the demand elasticity of the food products sold with the ViviVerde label (eggs, milk, fresh cheese, pasta, fruit juices) from de period of January 2010 to May 2012 in the Italian Province of Bologna. The conclusions are that economic performance of a line of products of the ViviVerde Coop, that clearly pursues the Corporate Social Responsibility objectives, is positive and increasing. It demonstrates that those kinds of brand management strategies can be successful.
\end{abstract}

Keywords: Brand management. Marketing. Consumer behavior. Elasticity of demand. Organic products.

\section{Resumo}

Devido ao crescimento econômico, as mudanças sociais, culturais e demográficos conduzem mudanças nos padrões de produção de alimentos. $O$ aumento dos níveis de instrução, urbanização e consequente despovoamento das zonas rurais, o aumento do número de mulheres que trabalham, o aumento da riqueza das famílias, o crescimento e diferenciação de demanda por alimentos levaram a inovações profundas nas prioridades e escolhas dos consumidores. Isto significa que os comportamentos de consumo são mais focados na segurança alimentar (busca de alimento seguro, saudável e até mesmo biológica) ao invés de segurança alimentar (o problema da escassez de alimentos não afeta mais os países desenvolvidos). Produtores e distribuidores de alimentos, em particular os de distribuição em grande escala, gradualmente adaptaram suas estratégias para atender às preferências dos consumidores emergentes. Neste artigo, analisa-se a estratégia de gestão da marca "ViviVerde" adotada por Coop e também faz-se uma análise da elasticidade da demanda dos produtos alimentares comercializados com o rótulo ViviVerde (ovos, leite, queijo fresco, massas, sucos de frutas) no período de janeiro de 2010 a maio 2012 na província italiana de Bolonha. As conclusões são que o desempenho econômico de uma linha de produtos da Coop ViviVerde, os quais adotam claramente os objetivos da Responsabilidade Social Corporativa, é positivo e crescente. Isso demonstra que estes tipos de estratégias de gestão de marca podem ser bem sucedidos.

Palavras-chave: Gerenciamento de marca. Marketing. Comportamento do consumidor. Elasticidade da demanda. Produtos orgânicos. 


\section{1 introduction}

During the last century, several important social changes occurred, due to the globalization phenomenon and the significant economic development. Those changes involved almost all aspects of people's lifestyle, with important consequences on the structure of the western society. For example, the global instruction rate is increased, the urbanization trends have led to the abandon of the rural areas, the female employment rate is grown, the global income level is increased, and the role and influence of the mass media has strengthened. Those phenomena have generated new levels of awareness and, consequently, new needs in the food consumers. As a result of those trends, substantial changes in the agri-food sector have occurred: those changes concern both productions and production systems that, from being local and based on the artisan production, have become more industrialized and delocalized (Inea, 2009; Belliggiano, 2009; Belletti; Marescotti, 1995).

In particular, the urbanization phenomenon has increased the distance between the consumers and the production sites. This results in a smaller consumers' trust, despite of a bigger availability of food: while the food security is greatly increased, the food safety tends to decrease (Inea, 2009). In addition to those phenomena, the agri-food sector has been often hit by scandals and frauds, such as the BSE ("mad cow"), avian and swine flu, the case of "blue mozzarellas", which have greatly affected the market for agri-food products, causing big economic losses (for the Italian agri-food sectors those losses due to the latest food safety issues are estimated in more than 15 billion of euros).

Moreover, the prominent role of the new media and the Internet has promoted a more complete knowledge of ethical issues relative to humanity as a whole and transformed the consumers from being recipient of unilateral information in purposeful subjects, able to communicate their preferences and needs and to influence the producers and the retailers of the agri-food sector. In this new context the modern consumer is then more aware of several "new" aspects of the food market and the quality/price concept assumes new connotations, which are more ethical and related to the food safety aspect. As a consequence, the traditional indicators used to predict the consumers behavior, such as price, relative prices, and income are not anymore sufficient the consumers choices, except through a deeper analysis of the subjective component of the choice, more related to the personal taste (Belliggiano, 2009).

The scope of this paper is to analyze and search for empirical evidences of the success and of failure, of a brand management policy related to the Corporate Social Responsibility (CSR) approach, defined by the European Union as a concept whereby companies integrate social and environmental concerns in their business operations and in their interaction with their stakeholders on a voluntary basis (European Commission, 2001). CRS is a strong base for the new marketing policies, where the consumers, considered as stakeholders, are informed about the policies pursued by the retailer, in order to increase its reputation and incomes (Pepe, 2003; Bisio, 2003, Tassinari, 2003; Ricotti, 2003; Cramer; Jonker; van der HeiJden, 2004; Unioncamere, 2004; Casati; Sali, 2005; Musso; Risso, 2006; Parmiggiani, 2007; Briamonte; Hinna, 2008; Giuca, 2008; Peri, 2008; Fabris, 2010).

With this paper we want to give a contribution to the studies related to the role of the Social Responsibility factor for the consumer. Literature evidences that there is a progressive transition, especially during crisis moments, from a "classic" typology of consumer, mainly interested in searching for the better price/ quality rate, to a consumer-citizen, more interested in understanding the dynamics and the ethics of the products he or she buys (Inea, 2009).

\section{Material and Methods}

In this study we analyze quantitatively the case of the ViviVerde line of biological products, in particular the economic performance of five typologies of products of the food sector: eggs, milk, fresh cheese, pasta, juice nectars. The scanner data has been provided by Coop Adriatica (17 proximity shops (InCoop), 29 stores (Coop and InCoop,) and 4 superstores (IperCoop) located in the Bologna province of Italy which goes from January 2010 to May 2012.

In this regards, we analyze the microeconomic results of these phenomena through the description of the elasticity of the demand curve of several food products of the biological line ViviVerde Coop. This analysis can describe the role of CSR policies on the Large Scale Retail subjects that adopt them, both in term of reliability and of increased revenue. The economic trend of products based on a strong CRS can be used to understand how the modern consumer descripted above reacts to this supply, and how this reaction leads the LSR subjects to define and protect a strong brand image, based on the consumer loyalty. Those aspects are fundamental to survive in the contemporary agri-food market, which has become more and more competitive.

The elasticity of the demand curve represents the variation of the sales related to the variation of the sale price. This index represent the direction of the 
changes in sold quantities: a positive value is indicative of an increasing in sales with increasing prices (and vice-versa), while a negative value is representative of decreasing sales with increasing prices (as happens with "classic" goods). Moreover, the absolute value of the elasticity has to be considered: for example, a value of 2 indicates that the variation of sales is $2 \%$ for every $1 \%$ of the price variation (the direction is done by the sign of the found value) (VARIAN, 2009).

Defining $\mathrm{P}$ as the price and $\mathrm{Q}$ as number of pieces sold for a given week, and $\mathrm{dP}$ and $\mathrm{dQ}$ respectively the variations of those values in a given time, elasticity of the demand curve e is defined as

$$
\varepsilon=\frac{\Delta \mathbf{Q} / \mathbf{Q}}{\Delta \mathbf{P} / \mathbf{P}}
$$

Another method for the estimation of elasticity, which will be used in this paper, is to perform a linear regression of the logarithmic transformation of $\mathrm{P}$ and Q. Given the function

$$
\log (\mathbf{Q})=\mathbf{a}+\operatorname{eLog}(\mathbf{P})+\varepsilon
$$

The estimated coefficient e, which is the slope of the regression line, represents the elasticity of the demand curve, if it is significant.

\section{Results and discussions}

\subsection{Economic trends for the ViviVerde Coop line} Coop Adriatica, a division of Coop Italia which operates in a several Italian regions, including Emilia-Romagna and its Province Bologna, owns 51 stores in the Province territory. Those stores are organized in different categories, according to their surface: (i) 17 superetteInCoop: small shops, located mainly in the city center, with a surface smaller than 1000 square meters; (ii) 29 supermarkets: Coop stores (bigger than 2000 square meters) and Coop\&Coopstores (smaller than 2000 square meters); (iii) 4 superstores Ipercoop and (iv) a Staibene Coop shop dedicated to wellness products. More than a half of the total stores surface $(60 \%)$ is located in the Bologna city territory. Of this surface, $40 \%$ is represented by the four superstores, followed by the Coop stores (38\%), the Coop\&Coop $(17 \%)$ and by the more recent superetteIncoop (3\%).

Concerning the analysis of the revenue, the biggest income share (45\%) is registered by the Coop stores. This is due to the strong presence of those shops in the Bologna province territory, which compensates the smaller surface. Another interesting data is the revenue of the In Coopsuperettes, which generates the $8 \%$ of the total Coop Adriatica sales. This shows that this typology of shop (called proximity shops) meets the needs of the consumers, in spite of the higher selling prices.

The success of the proximity shops shows that the consumers behavior is changing because of the crisis there is an increased level of attention for the food waste and an increased propensity to buy food from stores close to home. This is why Coop, such as other large scale retailers invested resources in the creation of small shops, located in the city center, that supply essential and mainly private label goods.

The InCoop trend is steadily increasing over the considered period where the share of ViviVerde products sold in the InCoop stores goes from the 7\% of 2010 to the $12 \%$ of the May 2012, while the value for the Coop\&Coop stores remains quite the same and the Coop and Ipercoop values decrease. We have considered the food products of the ViviVerde line, grouped in five macro areas: milk, pasta, fresh cheeses (ricotta, mozzarella and crescenza), fruit juices. For every product we have calculated the total sale value,

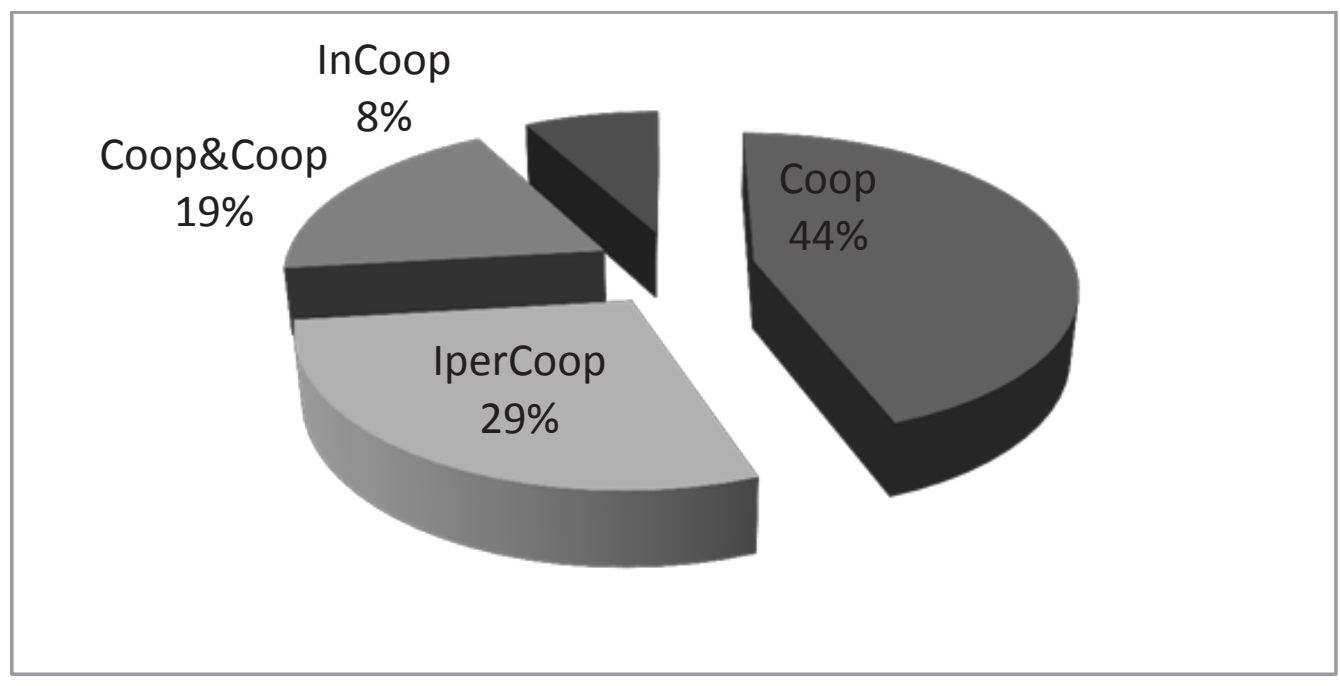

Figure 1 - Composition in percentage of ViviVerde food products sales in the Coop Stores (Jan 2010 - May 2012)

Source: Brasili et al. (2013). 


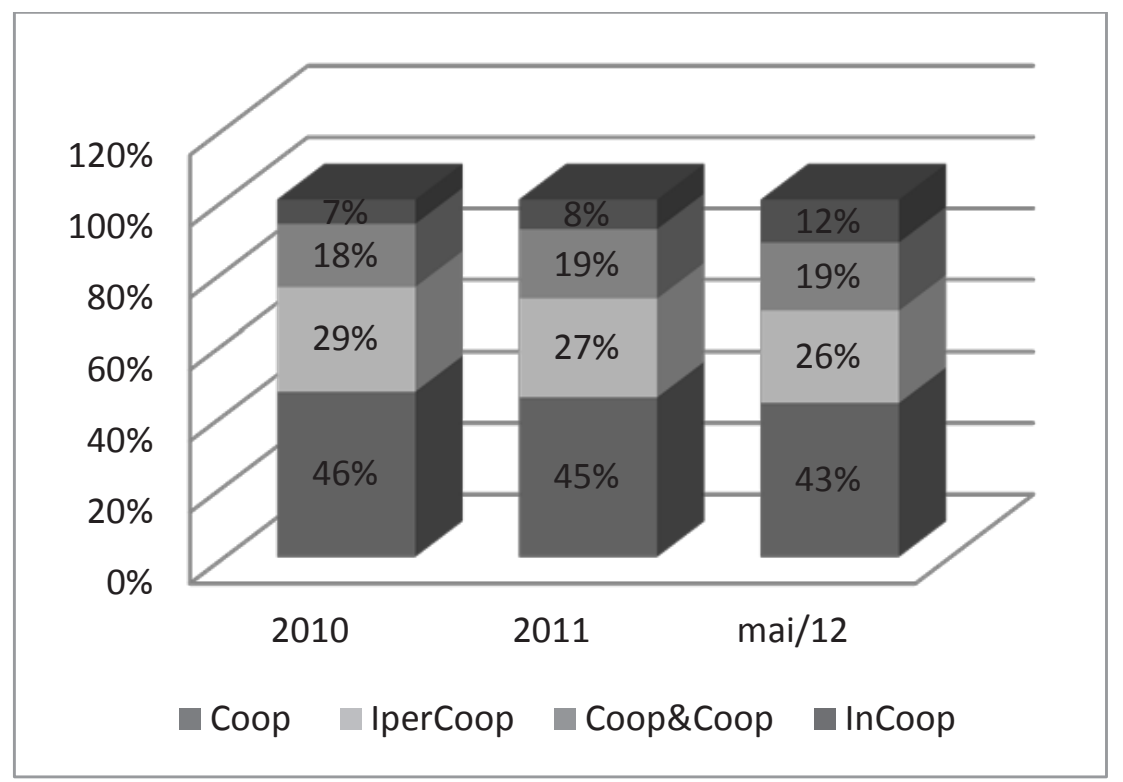

Figure 2 - Percentage of composition of ViviVerde food products sales in the Coop Stores, pieces sold (Jan 2010 - May 2012) Source: Brasili et al. (2013).

the number of pieces sold and the average price, in order to study the historic trend of sales from January 2010 to May 2012.

Those data show that the creation of a biological line linked to the Coop brand is a success story. All of the economic indexes related to those products shows positive trends in all of the four categories of stores analyzed. Concerning the database used for the analysis of the demand curve elasticity, it comprehends the sales data of all of the ViviVerde line products from January 2010 to May 2012 for the stores of the Bologna Province. Since the introduction of the ViviVerde products in the different shops has been gradual over time both for the different shop categories and for the single stores, we have not considered data for the stores open since January 2012.

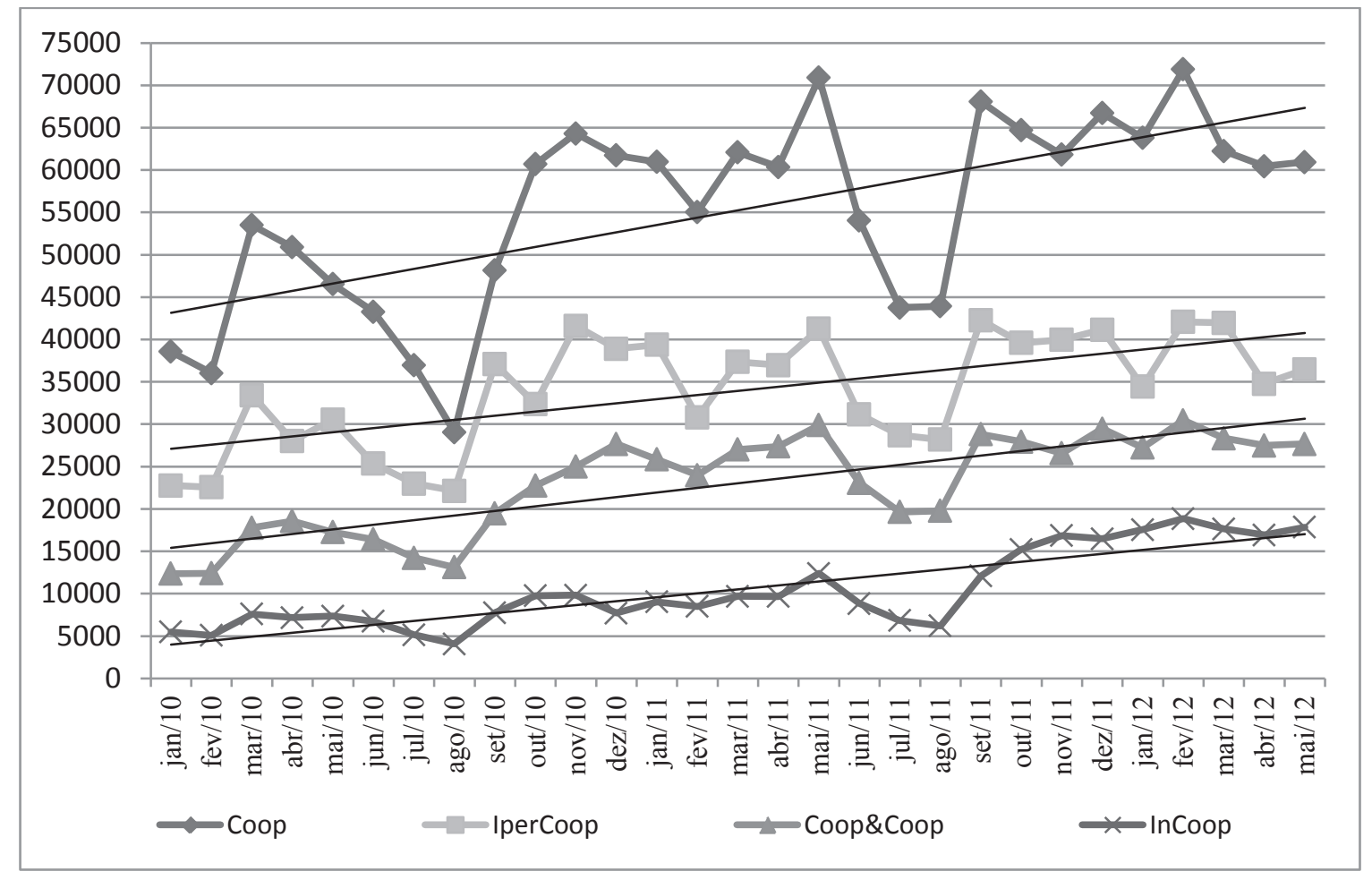

Figure 3 - Total revenue generated by sales of ViviVerdeCoop products (Jan 2010 - May 2012)

Source: Brasili et al. (2013). 
3.2 Elasticity results for the ViviVerde Coop line

Following are reported the results of the analysis of the elasticity of demand curve for the considered ViviVerde food products, for each store category. The correspondent coefficient of determination $\mathrm{R}^{2}$ provides a measure of how well observed outcomes are replicated by the model, as the proportion of total variation of outcomes explained by the model (the more the value is close to 1 , the better real outcomes are explained by the model).

As we can observe, there is not a unique trend in the results, but there are some unusual results where some values are positive, bigger than 1 and significant. This is unusual for food products that do not belong to the "luxury" category, where an increasing price is usually followed by a decreasing value of sales.

Those results can be observed from two points of view either store typology or good category. Concerning the store typology, the estimated value of elasticity, and so the effect of price on sales, is significant for every products sold in the proximity shops InCoop, while this is true only for some category of good in the other typologies (three cases for IperCoop superstores and for Coop\&Coop stores, one case for the Coop stores). Positive and bigger than 1 values in four typologies of product for the InCoop shops is probably due to the preference of the InCoop customers for the quality products, in spite of the increasing price.

The analysis of the different typologies of product gives "incoherent" results, that are completely different between the various stores: eggs, milk, pasta and fruit juices shows significant elasticity values for the InCoop shops, while this cannot be said for the other store typologies. Even the sign of the elasticity value is variable: products sold in the InCoop stores always have the sign of the elasticity value opposite to the one of the same products sold in the other stores. So, the price effect is negative for eggs, pasta and fruit juices sold by the InCoop shops, the Coop Stores and the IperCoop superstores.

A different result is given by the analysis of the fresh cheeses and milk data. When the elasticity value is significant (it is true for the milk in every typology of store and for the fresh cheeses in the Coop\&Coopstores and for the InCoop shops), it is also positive and bigger than 1. It means that the price effect is opposite to the one of the other goods: when the price rises, the sold quantities rises too.

\section{Conclusions}

We concluded that the success of this brand management policy strongly based on the Corporate Social Responsibility bases and demonstrate how the private label are becoming an ever more important and strategic asset for the Large Scale Retailers.

The study of the economic performance of a line of products, the ViviVerde Coop, that clearly pursues the CSR objectives, demonstrates that those brand management strategies can be successful. Those initiatives have a positive impact both on the reliability of the Large Scale Retailers and, especially, on the turnovers. ViviVerde is the more important line of products offered by Coop, both for the sales and for the number of references $(21.8 \%$ of the total referen-

Table 1 - Elasticity of the demand curve for ViviVerde food products for the Coop Adriatica stores located in Bologna Province

\begin{tabular}{l|c|c|c|c}
\hline & Coop & IperCoop & Coop\&Coop & InCoop \\
\hline \multirow{2}{*}{ Eggs } & -0.51 & -0.92 & 0.56 & $2.26^{* *}$ \\
& $\mathrm{R}^{2}=0.03$ & $\mathrm{R}^{2}=0.08$ & $\mathrm{R}^{2}=0.02$ & $\mathrm{R}^{2}=0.22$ \\
\hline \multirow{2}{*}{ Milk } & -0.62 & 2.86 & $2.3^{*}$ & $-2.06^{*}$ \\
& $\mathrm{R}^{2}=0.01$ & $\mathrm{R}^{2}=0.09$ & $\mathrm{R}^{2}=0.1$ & $\mathrm{R}^{2}=0.12$ \\
\hline \multirow{2}{*}{ Fresh cheeses } & $-2.57^{*}$ & $-3.17^{*}$ & $-2.71^{* *}$ & $2.38^{* *}$ \\
& $\mathrm{R}^{2}=0.66$ & $\mathrm{R}^{2}=0.43$ & $\mathrm{R}^{2}=0.63$ & $\mathrm{R}^{2}=0.48$ \\
\hline \multirow{2}{*}{ Pasta } & -0.89 & $-2.09^{*}$ & -0.23 & $4.92^{* *}$ \\
& $\mathrm{R}^{2}=0.04$ & $\mathrm{R}^{2}=0.23$ & $\mathrm{R}^{2}=0$ & $\mathrm{R}^{2}=0.12$ \\
\hline \multirow{2}{*}{ Juice fruits } & 0.35 & $-1.61^{*}$ & $-2.24^{*}$ & $3.58^{* *}$ \\
& $\mathrm{R}^{2}=0.008$ & $\mathrm{R}^{2}=0.13$ & $\mathrm{R}^{2}=0.18$ & $\mathrm{R}^{2}=0.29$ \\
\hline
\end{tabular}

$* *=5 \%$ significance $*=10 \%$ significance.

Source: Brasili et al. (2013). 
ces with the Coop private label) and the first private label line of the Italian market. This success is mostly due to the awareness that this Large Scale Retailer have created in its customers about the topics of the CSR. So, when the biological line has been proposed, consumers were "ready" to buy this kind of products.

The analysis of the demand curve elasticity of those products shows that "incoherent" results, both are concerning the product typology and the category of the store in which they are sold. In several cases the elasticity value is positive and bigger than 1 meaning that the effect of an increasing price is to increase the consumption too. This enforces the idea that the main driver for the InCoop customers purchasing is not only the price, but also the ethical values that are transmitted by the ViviVerde Coop brand such as quality, safety, and respect for the environment and so on. An interesting consequence is that those consumers are willing to pay a higher price to buy this typology of goods.

\section{Ackowlegments}

This paper was partially developed during the exchange program carried on by Prof. Dr. Andréa Cristina Dörr at the University of Goettingen, Germany during April-May, 2013 financed by CAPES/DAAD (Edital DRI/DCGI no 58/2010).

\section{References}

Belletti, G.; Marescotti, A. Le nuove tendenze nei consumi alimentari. In: Begalli, D.; Berni P. (Ed.). I prodotti agroalimentari di qualità: organizzazione del sistema delle imprese. Atti del XXXII Convegno di Studi Sidea, 1995.

Belliggiano, A. Percezione della sicurezza alimentare e nuovi modelli di organizzazione della produzione. Rivista di Diritto Alimentare, ano 3, n. 4, 2009.

Bisio, L. Corporate Responsibility and Corporate Governance in Europe. SYMPHONYA Emerging Issues in Management, Milano: Istei - Istituto di Economia d'Impresa Università degli Studi di Milano - Bicocca, n. 1, 2003.

Brasili, C. et al. La linea commerciale Vivi Verde Coop, andamenti, diffusione e prospettive future nella Provincia di Bologna. Quaderni di Dipartimento. Serie Ricerche, Dipartimento di
Scienze Statistiche "Paolo Fortunati", Alma Mater Studiorum. Bologna: Università di Bologna, 2013.

Briamonte, L.; Hinna, L. (Ed.). La responsabilità sociale delle imprese del sistema agroalimentare. Roma: Studi e Ricerche Inea, 2008.

Casati, D.; Sali, G. (Ed.). Il contenuto sociale dei prodotti. Indagine sul consumo responsabile. Milano: Franco Angeli, 2005.

Cramer, J.; Jonker, J.; van der Heijden, A. Making sense of corporate social responsibility. Journal of Business Ethics, v. 55, n. 2, p. 215-222, 2004.

European Commission. EC. Green paper: promoting a european framework for corporate social responsibility, COM (2001) 366, Bruxelles, 18 jul. 2001.

Fabris, G. La società post-crescita: consumi e stili di vita. Egea, 2010.

Giuca, S. Responsabilità sociale di impresa come valorizzazione della territorialità e della tradizione agroalimentare. In: Briamonte, L.; Hinna, L. (Ed.). La responsabilità sociale per le imprese del settore agricolo ed agroalimentare. Roma: Inea, 2008.

INEA. Comportamenti e consumi socialmente responsabili nel sistema agroalimentare. Roma: Studi e Ricerche Inea, 2009.

Musso, F.; Risso, M. Responsabilità sociale d'impresa nelle filiere internazionali della grande distribuzione. SYMPHONYA EmergingIssues in Management, Milano: Istei - Istituto di Economia d'Impresa Università degli Studi di Milano Bicocca, n. 1, 2006.

Parmiggiani, M. L. Il consumatore e la RSI. Sociologia del Lavoro, n. 108, 2007.

Pepe, C. Global retailers and corporate responsibility. SYMPHONYA Emerging Issues in Management, Milano: Istei - Istituto di Economia d'Impresa Università degli Studi di Milano Bicocca, n. 1, 2003.

Peri, I. Responsabilità sociale di impresa, agricoltura e ambiente: implicazioni e applicazioni. In: Briamonte, L.; Hinna, L. (Ed.). La responsabilità sociale per le imprese del settore agricolo e agroalimentare. Napoli: Edizioni Scientifiche 
Italiane, 2008. p. 99-106.

Ricotti, P. Corporate responsibility, compatibilità e mercati. SYMPHONYA EmergingIssues in Management, Milano: Istei - Istituto di Economia d'Impresa Università degli Studi di Milano Bicocca, n. 1, 2003.

Tassinari, V. Social responsibility in supply chain: the Coop Italia Case. SYMPHONYA Emerging Issues in Management, Milano: Istei - Istituto di Economia d'Impresa Università degli Studi di Milano - Bicocca, n. 1, 2003.

Unioncamere. I modelli di responsabilità sociale delle imprese italiane. Milano: Franco Angeli, 2004.

VARIAM, H. R. Intermediate microeconomics: a modern approach. Norton, ed. 8, 2009. 